\title{
Złe czyny mieszkańców Sodomy (Rdz 19,1-11) w interpretacji św. Augustyna
}

\author{
The Wicked Acts of the Inhabitants of Sodom (Gen 19:1-11) \\ in the Interpretations of St. Augustine
}

\section{SYLWESTER JAŚKIEWICZ}

Katolicki Uniwersytet Lubelski Jana Pawła II

sylwester.jaskiewicz@kul.pl, ORCID: 0000-0002-4941-3610

\begin{abstract}
Streszczenie: Celem artykułu jest przedstawienie zachowania mieszkańców Sodomy wobec dwu podróżnych (aniołów), przyjętych na nocleg przez Lota (Rdz 19,1-11), obecnego w nauczaniu św. Augustyna. U biskupa Hippony odnajdujemy szereg terminów określających to zachowanie: flagitia, facta mala, iniquitates et perversitates, scelera czy peccatum. Równie interesujące jest dostrzeżenie wpływu, jaki na Augustyna interpretację czynów mężczyzn z Sodomy wywarł swoimi poglądami Julian z Eklanum. To głównie za jego sprawą ocena występku mieszkańców Sodomy przesunięta została przez biskupa Hippony ze sfery ogólnych wykroczeń przeciw naturze (contra naturam) do sfery zachowań seksualnych i na trwałe powiązana z obcowaniem płciowym (stuprum) mężczyzn.
\end{abstract}

Słowa kluczowe: złe czyny, Sodoma, św. Augustyn, Julian z Eklanum, pożądliwość

Abstract: The aim of the article is to present the behavior of the inhabitants of Sodom towards two travelers (angels) taken in overnight by Lot (Gen 19: 1-11), according to the teaching of St. Augustine. In the Bishop of Hippo we find a number of Latin terms describing this behavior: flagitia, facta mala, iniquitates et perversitates, scelera or peccatum. It is equally interesting to see the influence that Julian of the Eclanum had on Augustine's interpretation of the deeds of the Sodomites. It was mainly due to Julian that Augustine's assessment of the transgression of the men of Sodom perceptively shifted, from the sphere of general offenses against nature (contra naturam), to the sphere of sexual behavior, to become permanently and specifically associated with sexual intercourse with men.

Keywords: bad deeds, Sodom, St. Augustine, Julian of the Eclanum, concupiscence

Dzieje grzechu Sodomy (Rdz 19,1-11), stanowiące nieodłączną część opowiadania o zniszczeniu Sodomy i Gomory (Rdz 19,1-29), należą do motywów dobrze znanych nie tylko w Biblii, ale i w wyrastającej z niej tradycji Kościoła, a także w karmiącej się nią literaturze i sztuce. W pismach wczesnochrześcijańskich, tak zresztą jak w tradycji judaistycznej, grzech mieszkańców biblijnego miasta kananejskiego, położonego w dolinie Siddim nad Morzem Martwym, jest paradygmatem niegościnności, pychy, wykorzystywania obcych, bezbożności i nieposłuszeństwa ${ }^{1}$. Nowa tendencja,

1 Por. Justyn Męczennik, 1 Apologia 53.7-53.8; Ireneusz, Przeciw herezjom IV, 36.3; Orygenes, Przeciw Celsusowi II, 67. Zob. Loader, A Tale of Two Cities. 
prowadząca do utożsamiania grzechu Sodomy z grzechem, o którym uczy św. Paweł w Rz 1,27, uwidacznia się na przełomie IV i V wieku². Zwłaszcza z tym drugim znaczeniem wielu współczesnych autorów łączy osobę św. Augustyna i przypisuje mu, wraz z np. Makariuszem z Egiptu, wyakcentowanie seksualnej natury występków, a przede wszystkim potępienie homoseksualizmu3. Jego wpływ na Zachodzie jest niekiedy zestawiany z wpływem, jaki na chrześcijańskim Wschodzie odegrał św. Jan Chryzostom, biskup Konstantynopola ${ }^{4}$. Pewnym ukoronowaniem homoseksualnej interpretacji grzechu Sodomy jest obecny od średniowiecza termin sodomia ${ }^{5}$.

Pytanie: Czym właściwie był grzech Sodomy? pojawiło się z nową mocą w dokumencie Papieskiej Komisji Biblijnej „Czym jest człowiek?” (Ps 8,5). Zarys antropologii biblijnej ${ }^{6}$. A choć dokument ten udziela wiążącej odpowiedzi, to jednak uznaje także za konieczne „przebadanie fragmentów Pisma Świętego, w których porusza się problematykę homoseksualną, w szczególności tych, gdzie się ją gani i potępia”7. To wskazanie odnosi się także do tak znaczącego interpretatora Biblii na Zachodzie, jakim był biskup Hippony, zwłaszcza z uwagi na jego olbrzymi wpływ na teologię chrześcijańską.

\section{Refleksja św. Augustyna nad biblijnym tekstem Rdz 19,1-11}

Trudno nie przyznać racji francuskiemu jezuicie Bertrandowi de Margerie, który mówiąc o mniej pozytywnych stronach egzegezy biskupa Hippony, zauważył, że w zestawieniu z egzegezą Orygenesa czy Hieronima jest ona mocno ograniczona ${ }^{8}$. Ta uwaga odnosi się zwłaszcza do tekstów Starego Testamentu, którym chociaż - jak w przypadku Księgi Rodzaju - biskup Hippony poświęca aż cztery systematyczne komentarze (De Genesi contra Manichaeos libri duo [388-389], De Genesi ad Litteram imperfectus Liber [393], Confessionum libri XI-XIII [403], De Genesi ad Litteram libri duodecim [404-415]), dzieła o charakterze egzegetycznym (Locutionum in Heptateuchum libri septem [419], Questionum in Heptateuchum libri septem [419], Contra adversarium legis et prophetarum liber I [420]), mowy (Sermones 1-5 [403-411]),

2 Por. Ahern, „The Sin of Sodom”, 229.

3 Por. Carden, Sodomy, 128-129; Lemański, Ksiega Rodzaju, 391; Loader, A Tale of Two Cities, 133-134; Sodoma distrutta, 31-33.

4 Por. Crompton, Homosexuality and Civilization, 137; Grassi, Sodoma, 29; Lewandowski, Grzech sodomii, 31-34.

5 Marc D. Jordan (The Invention of Sodomy, 1-2) uważa termin „Sodoma” (ang. Sodomy) za średniowieczny artefakt, jako kategorię służącą do klasyfikowania pragnień, dyspozycji i czynów, przy czym jego obecności nie zauważa do XI wieku. Zob. także: Lemański, Księga Rodzaju, 392.

6 Por. Papieska Komisja Biblijna, „Czym jest człowiek?”, 149.

7 Papieska Komisja Biblijna, „Czym jest człowiek?”, 149.

8 Por. de Margerie, Introduction, 170-171. 
a także liczne miejsca w innych dziełach (np. De civitate Dei). Tylko w Questionum in Heptateuchum libri septem Augustyn podejmuje rozważania nad trzema wybranymi wierszami Księgi Rodzaju - 19,1.8.11. Choć wypowiedzi myśliciela z Tagasty nie mają wartości stricte egzegetycznej, to jednak zawierają cenne elementy teologii biblijnej, które stanęły u podstaw chrześcijańskiej cywilizacji, zwanej zachodnią. Jednym z nich, w kontekście Księgi Rodzaju, jest duże zainteresowanie pierwszym z trzech największych patriarchów, protoplastą Izraelitów i innych plemion semickich, Abramem (Abrahamem) ${ }^{9}$. To w jego cieniu wyrasta szczególnie cenna w opowiadaniu o Sodomie osoba jego krewnego Lota. Abram uwalnia Lota i przyczynia się do zwycięstwa królów sodomskich ${ }^{10}$. W Questionum in Heptateuchum libri septem biskup Hippony podkreśla jego gościnność względem nieznanych przybyszów, gotowość do poświęcenia nawet swych córek, pochwala jego cześć do „jednego Boga prawdziwego" oraz to, że nie dał się nakłonić do zła, jakie wówczas rządziło mieszkańcami Sodomy. W spisie herezji mieszkańcy Sodomy są wymieniani wraz z potomkami Kaina. Bluźnili oni przeciw Prawu i Bogu, od którego Prawo pochodzi1"

Święty Augustyn, jako tractator divinorum eloquiorum, niejednokrotnie przedmiotem swych rozważań czyni poszczególne biblijne wydarzenia, osoby lub fakty ${ }^{12}$. Za przykładem apostoła Pawła, celem wywołania większego wrażenia na słuchaczach, rozmiłowany był w antytezach, obrazach i hiperbolach. Często w swych rozważaniach posługuje się pojedynczymi faktami (facta), aby wyjaśnić związany z nimi czy też odrębny problem: objawienia się Boga $\mathrm{w}$ dwu aniołach Lotowi ${ }^{13}$; zapowiedzi zagłady (interitus) Sodomy ${ }^{14}$; niestosowności używania kłamstwa, aby przyczynić się do zbawienia innych ${ }^{15}$; wymierzania kar przez dobrych aniołów ${ }^{16}$. Czasami zatrzymuje się nad obrazem słynnego ognia i zniszczenia ${ }^{17}$, a niekiedy nad znaczeniem

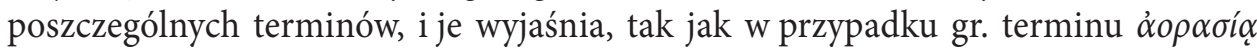
(„niedowidzenie”, „ślepota”) ${ }^{18}$.

Sodoma dla biskupa Hippony to najkrócej regio impiae civitatis $^{19}$. O niegodziwości biblijnego miasta najdobitniej stanowią przypisywane mu: flagitia („czyny ha-

9 Por. Vaccaro, „Abramo”, 105.

10 Por. Augustinus, De civitate Dei 16, 22 (Kubicki, 619).

11 Por. Augustinus, De Haeresibus ad Quodvultdeum liber unus 18.

12 Por. Grossi, Leggere, 51.

13 Por. Augustinus, Contra Maximinum haereticum 2, 26, 5-6; Augustinus, De civitate Dei 16, 29 (Kubicki, 628).

14 Por. Augustinus, Contra Maximinum haereticum 2, 26.5.

15 Por. Augustinus, De mendacio liber unus 7, 10.

16 Por. Augustinus, Enarrationes in Psalmos 77, 29 (PSP 39, 396).

17 Por. Augustinus, Contra secundam Iuliani responsionem imperfectum opus 3, 12.

18 Por. Augustinus, De civitate Dei 22, 19 (Kubicki, 940); Augustinus, Questionum in Heptateuchum 1, 43.

19 Por. Augustinus, De civitate Dei 16, 30 (Kubicki, 629). 
niebne”, „grzechy”) ${ }^{20}$, facta mala („złe czyny”) ${ }^{21}$, iniquitates et perversitates („niegodziwości i przewrotności”) $)^{22}$, scelera („występki” $)^{23}$, peccatum („grzech”) ${ }^{24}$, manifesta peccata („grzechy publicznie znane”) ${ }^{25}$. Patrząc na los mieszkańców Sodomy z perspektywy Nowego Testamentu doktor Kościoła przypomina także, że ich ostateczny los znośniejszy będzie od losu mieszkańców Judei, a więc tych, którzy - pomimo tylu cudów - nie uwierzyli w Jezusa Chrystusa ${ }^{26}$, a także, że Zbawiciel, mówiąc o ludziach z Sodomy, myślał o innych grzesznikach ${ }^{27}$.

W całościowym ujęciu i systematyzacji głównych wątków refleksji św. Augustyna nad źródłowym opisem winy mieszkańców Sodomy (Rdz 19,1-11) zwykło zwracać się uwagę na fakt, że zwłaszcza od XVI księgi De civitate Dei ${ }^{28}$ kładzie on wyraźny nacisk na homoseksualne rozumienie grzechu mieszkańców Sodomy ${ }^{29}$. Tak więc w interpretacji natury złych czynów ludzi z Sodomy uwidaczniają się w spuściźnie literackiej biskupa Hippony zasadniczo dwa kierunki czy też nurty, które ogólnie można określić jako: 1) grzechy przeciw naturze oraz 2) nierząd mężczyzn z mężczyznami (stupra in masculos).

\section{Grzechy przeciw naturze}

Jedno z najwcześniejszych świadectw mówiących o złych czynach mieszkańców Sodomy, o ich - jak wynika z szerszego kontekstu - grzechu, znajduje się w traktacie Contra Faustum Manichaeum libri triginta tres. W dziele tym biskup Hippony odpiera zarzuty manichejskiego biskupa Faustusa z Milewum, z którym spotkał się po raz pierwszy pod koniec 382 r., gdy stopniowo odchodził już od manicheizmu. To najdłuższe dzieło antymanichejskie myśliciela z Tagasty powstało prawdopodobnie pomiędzy rokiem 398 a $400^{30}$. W księdze XXII biskup Hippony odpiera zarzut

20 Por. Augustinus, Confessiones 3, 8, 15: „Itaque flagitia, quae sunt contra naturam, ubique ac semper detestanda atque punienda sunt, qualia Sodomitarum fuerunt” (Kubiak, 43: „Dlatego grzechy przeciw naturze, jak te, które popełniali sodomici [...]").

21 Por. Augustinus, Enarrationes in Psalmos 69, 2 (PSP 39, 224).

22 Por. Augustinus, Enarrationes in Psalmos 128, 2 (PSP 42/1, 54).

23 Por. Augustinus, Questionum in Heptateuchum 1, 45 (PSP 46/1, 31).

24 Por. Augustinus, Contra secundam Iuliani responsionem imperfectum opus 4, 128.

25 Por. Augustinus, Adnotationes in Iob liber unus, 30.

26 Por. Augustinus, Enarrationes in Psalmos 118 (25), 3 (PSP 42/1, 313).

27 Por. Augustinus, Contra Iulianum libri sex 5, 11.44 (PSP 19/2, 212).

28 Dokładna data napisania XVI księgi jest nieznana. Umiejscawia się ją wraz z księgą XV po napisaniu Quaestionum in Heptateuchum libri septem i Locutionum in Heptateuchum libri septem. Te dwa dzieła napisane zostały w latach 419-420. Por. „Tavola delle opere di Agostino. Note”, 66.

29 Por. Ahern, „The Sin of Sodom”, 209-210; Jordan, The Invention of Sodomy, 34-35; Loader, A Tale of Two Cities, 136.

30 Por. Coyle, „Faustum Manichaeum, Contra”, 712. 
Faustusa, jakoby chrześcijanie byli przeciwnikami Prawa i Proroków. Zanim jednak podejmie się charakterystyki wybitnych postaci biblijnych i rozpatrywania ich pozytywnych oraz negatywnych cech, uważa za stosowne dać wstępne określenie, czym jest sam grzech.

Otóż grzechem jest czyn, powiedzenie, pragnienie jakieś przeciwko prawu wiecznemu. Natomiast prawo wieczne, to boska racja albo też wola Boga nakazująca zachowanie porządku naturalnego, a zabraniająca naruszania $\mathrm{go}^{31}$.

Związek grzechu z porządkiem odsłania polisemantyczność terminu ordo („porządek"), który przez biskupa Hippony jest w pierwszej kolejności rozumiany jako: ordo rerum omnium, ordo divinae providentiae (ordo Dei, ordo divini, ordo naturae, ordo causarum), ordo caritatis albo ordo universitatis ${ }^{32}$. Bóg - Stwórca wszystkich stworzeń - swą odwieczną wolę zawarł w prawie wiecznym, czyli w porządku natury, któremu zdaniem biskupa Hippony, w żaden sposób nie sprzeniewierzył się Abraham. Również w odniesieniu do Lota Augustyn wypowiada się bardzo pozytywnie.

Natomiast Lot, jego brat, sprawiedliwy i gościnny wśród Sodomitów, ale czysty i nieskalany ich zarazą, zasłużył na uniknięcie bez szwanku owego pożaru, który był podobieństwem przyszłego sądu. On to nosi w sobie obraz ciała Chrystusa, które również i obecnie pomiędzy niegodziwymi i bezbożnymi jęczy w osobie wszystkich świętych, bo nie godzi się na ich uczynki, a przy końcu świata zostanie wyzwolone od przebywania z nimi, kiedy to zostaną potępieni na karę ognia wiecznego ${ }^{33}$.

Wysunięcie przez Augustyna na pierwszy plan uwagi sprawiedliwości i gościnności Lota nie jest przypadkowe. Zapewne utwierdzał go w takim przekonaniu także jakiś bliski autorytet, jak chociażby biskupa Mediolanu ${ }^{34}$. Lot jest przeciwieństwem mieszkańców Sodomy i ich stanu, który oddaje rzeczownik contaminatio („plama”, „zepsucie”). Co więcej, dla biskupa Hippony jest on także figurą Kościoła, czyli ciała Chrystusa, które tak jak kiedyś, tak również i dziś, ma do czynienia z ludźmi niegodziwymi i bezbożnymi. Na pozytywny obraz Lota decydujący wpływ ma ostatecznie nie jego osobista sprawiedliwość, ale fakt, że jest on bratankiem Abrahama.

Zresztą i Lot brat, to znaczy krewniak Abrahama, pod żadnym pozorem nie może być porównywany do tych, o których Bóg powiedział: „Jam jest Bóg Abrahama, i Bóg Izaaka i Bóg Jakuba” (Wj 3,6). I nie trzeba go zaliczać do tych, którym Pismo Święte aż do końca wy-

\footnotetext{
Augustinus, Contra Faustum 22, 41 (PSP 56, 26).

Por. Pacioni, „Ordine”, 1029.

Augustinus, Contra Faustum, 22, 41 (PSP 56, 35-36).

Por. Ambroży, Hexaemeron 5, 54 (PSP 4, 169); List 74, 105 (BOK, 245).
} 
stawia świadectwo sprawiedliwości, chociaż pośród Sodomitów żył pobożnie i odznaczał się czystością. Ale i również przez zasługi gościnności został wybawiony od pożaru, jaki dotknął tę ziemię, jego zaś potomkom została przyznana darem Bożym (por. Rdz 19,2 nn.) w posiadanie ziemia ze względu na Abrahama, jego stryja ${ }^{35}$.

Wzmianka o mieszkańcach Sodomy w natężonej na Lota uwadze Augustyna jest nieznaczna. Lot żył pośród Sodomitów, ale prawdopodobnie nie tak jak oni, o czym świadczy łaciński spójnik quamvis („chociaż”, „jakkolwiek”). Pochwała pobożności, czystości i gościnności Lota ze strony Augustyna rzuca więc światło na ludzi z Sodomy, choć w samej wypowiedzi Augustyna nie ma bliższej charakterystyki ich postawy.

Kolejne ważne świadectwo znajdujemy w III księdze Wyznań. Jeśli powstanie tego dzieła św. Augustyna datuje się na lata $397-401^{36}$, to księga III powstała zapewne jeszcze przed 400 rokiem.

Dlatego grzechy przeciw naturze, jak te, które popełniali Sodomici, wszędzie i zawsze zasługują na potępienie i karę. Choćby je popełniały wszystkie ludy, wszystkie byłyby na mocy prawa Bożego uznane za tak samo zbrodnicze. Bóg bowiem nie stworzył ludzi do tego, żeby się sobą w taki sposób posługiwali. Kiedy wspólną naturę, której On jest Twórcą, bruka się przewrotną namiętnością, jednocześnie pogwałcona zostaje wspólnota, jaka powinna nas łączyć z Bogiem ${ }^{37}$.

Wyakcentowane przez biskupa Hippony "grzechy przeciw naturze” (flagitia contra naturam) mieszkańców Sodomy są ogólną nazwą wykroczeń, a to oznacza, że sam występek nie został tu dokładnie określony ${ }^{38}$. W próbie bardziej szczegółowej charakterystyki "grzechu przeciw naturze” należy w pierwszej kolejności podkreślić, że chwalona przez Pismo Święte gościnność była jednym z podstawowych praw porządku naturalnego ${ }^{39}$. Eva Anagnostou-Laoutides w swym opracowaniu na temat szerszych podstaw chrześcijańskiego negatywnego nastawienia wobec homoseksualizmu, a zwłaszcza pojmowania go jako luxuria („nadmiar”, „przepych”, „chęć użycia”) przeciw naturze, postuluje dowartościowanie stoickiej etyki seksualnej. Jej zdaniem należy zwrócić większą uwagę na rzymskiego pisarza Gaiusa Suetoniusa Tranquillusa (ok. 69-130), który choć sam nie był stoikiem, to jednak w swym De vita Caesarum zawarł lubieżne opisy homoseksualnych występków oraz stoickie teksty doktrynalne,

\footnotetext{
35 Augustinus, Contra Faustum, 22, 60 (PSP 56, 50).

36 Van Fleteren, „Confessiones (Le confessioni)”, 449.

37 Por. Augustinus, Confessiones 3, 8, 15 (Kubiak, 43).

38 Por. Ahern, „The Sin of Sodom”, 224; Grassi, Sodoma, 29; Jordan, The Invention of Sodomy, 34; Lewandowski, Grzech sodomii, 32-33.

39 Por. Daniélou, Święci „poganie”, 78.
} 
takie jak te Gaiusa Muzoniusza Rufusa (ok. 20 - po 101) ${ }^{40}$. Z drugiej strony znajdziemy też głosy przypisujące Augustynowi oczyszczenie teologii chrześcijańskiej z naleciałości stoickich i manichejskich ${ }^{41}$. Eoghan Ahern mówi o wpływach, jakie na rozumienie peccatum contra naturam przez biskupa Hippony wywarly pisma Filona z Aleksandrii, Justyna, Jana Chryzostoma, Ambrożego czy Pawła Orozjusza ${ }^{42}$. Augustyn, co potwierdzi zwłaszcza jego krytyka teologii bajecznej i kultów pogańskich, sprzeciwiał się stanowczo, jako niezgodnemu z naturą, , aby mężczyźni brali na siebie rolę płci kobiecej”ł3.

Wzmiankę o złych czynach mieszkańców Sodomy odnajdujemy w kazaniach biskupa Hippony, z których najstarsze zostało wygłoszone w Hipponie na przełomie 411 i 412 roku.

„Czasy bowiem nasze jeszcze bardziej są napiętnowane owym «Biada», które wypowiadał Pan: «Biada światu dla zgorszenia» (Mt 18,7). A ponieważ nieprawość przebrała miarę, stygnie miłość wielu" (Mt 24,12). Przecież i ów święty Lot, w Sodomie nie cierpiał jakiegoś prześladowania fizycznego, ani też nie powiedziano do niego, żeby tam nie mieszkał. Jego prześladowaniem stały się złe czyny Sodomitów $(\operatorname{Rdz} 19)^{44}$.

Augustyn nie miał najmniejszej wątpliwości, że zło, i to każdego rodzaju, oddziałuje na innych. Najpierw więc wyraźnie i stanowczo dodaje, że czyny mieszkańców Sodomy nie były dobre, ale złe. Lot poprzez swoją nieprzejednaną cześć wobec ,jednego Boga prawdziwego" znalazł się w opozycji do ludzi z Sodomy, którzy rosnąc w siłę i ufając swojej mocy, zaczęli cechować się pychą i bezbożnictwem, a przy tym wrogo odnosić się do przybyszów. Za zewnętrznymi postawami mieszkańców Sodomy kryło się tak naprawdę ich wewnętrzne nieuporządkowanie, zwłaszcza niegodziwość i przewrotność.

Kiedy indziej jedynie w osobie Abrahama był kościół, a wiemy ile zniósł on ze strony niegodziwych. W osobie jednego tylko syna jego brata, w osobie Lota i w jego domu w Sodomie był kościół, i znosił niegodziwość i przewrotność mieszkańców Sodomy, aż Bóg wybawił go spośród nich $(\operatorname{Rdz} 19,4)^{45}$.

Proces pokonania niegodziwości i przewrotności, tak w podmiocie jednostkowym, jaki i wspólnotowym, nie jest łatwy. W procesie tym konieczny jest wysiłek

\footnotetext{
40 Por. Anagnostou-Laoutides, „Luxuria and Homosexuality”, 7-14.

41 Por. Skrzydlewski, Etyka seksualna, 14-15.

42 Por. Ahern, „The Sin of Sodom”, 214-224. Zob. Crompton, Homosexuality and Civilization, 137; Grassi, Sodoma, 27; Hogan, „Homosexualität”, 154-155.

43 Augustinus, De civitate Dei 6, 8 (Kubicki, 237). Por. Spindelböck, „Die sittliche”, 168.

44 Augustinus, Enarrationes in Psalmos 69, 2 (PSP 39, 224).

45 Augustinus, Enarrationes in Psalmos 128, 2 (PSP 42/1, 54).
} 
człowieka, jego cierpliwość, ale ostateczne zwycięstwo daje Bóg poprzez swoją łaskę. Biskup Hippony przestrzega przed zaciemnieniem i uzależnieniem, jakie rodzi zło grzechu w człowieku, i wyjaśnia je na przykładzie ludzi z Sodomy, dla których nikczemność (nequitia) stała się sprawiedliwością (iustitia) ${ }^{46}$.

Postawa mieszkańców Sodomy jest dla Augustyna okazją, aby pouczyć swoich słuchaczy o nawarstwianiu się zła w człowieku, a więc w pierwszej kolejności o tym, jak powstają mala consuetudine („złe nawyki”). Doktora Kościoła do tego stopnia przeraża powstała w wyniku złego przyzwyczajenia turpitudo („szpetność”, „ohyda”) mieszkańców Sodomy, że porównuje ją do cuchnącego grobu. Ostatecznie jednak nie można zapomnieć, że niegodziwość czy przewrotność ludzka, choćby nawet największa, nie ma ostatniego słowa. Lot, pomimo tego że jego życie związało się z życiem mieszkańców Sodomy, a więc także z ich obyczajowością, nie uległ jednak ich wpływom.

„Przez pamięć na Abrahama Bóg ocalił Lota od zagłady” (Rdz 19,29). Pismo Święte podkreśla, że to raczej dzięki zasługom Abrahama Lot został wybawiony. Chodzi o to, żebyśmy zrozumieli, iż Lot został nazwany sprawiedliwym przede wszystkim z tego względu, że czcił jednego Boga prawdziwego, oraz dlatego, że w porównaniu z występkami Sodomitów, wśród których żył, nie dał się nakłonić do prowadzenia życia podobnego do ich postępowania ${ }^{47}$.

Fakt, że Lot nie pozwolił nakłonić się do zła ma dla biskupa Hippony także wymiar pedagogiczny, wychowawczy. Do faktu gościnności Lota biskup Hippony powraca także niemalże już u kresu swego życia, gdy po dyspucie teologicznej z ariańskim biskupem Mediolanu Maksyminem, znanym jako biskup Gotów, w latach 427-428 nie daje za wygraną i stara się w kolejnym dziele utwierdzić w tym, co wyraził już w dyspucie. W odniesieniu do gościnności Abrahama i Lota zostaje przypomniane także świadectwo autora Listu do Hebrajczyków ${ }^{48}$.

Najważniejszym autorytetem, a zarazem wiodącym punktem odniesienia rozważań biskupa Hippony jest Pismo Święte, które pochwala gościnność, nawet jeśli często mówi też o pogwałceniu tego prawa. Gościnność Lota uwidacznia także zachowanie podstawowego prawa nietykalności, i choć Augustyn wie doskonale, z jakimi trudnościami Lot spotkał się w zachowaniu tego prawa, to jednak woli o tym tu nie mówić.

46 Augustinus, Sermo 98, 5: „W tym mieście takie ohydne zepsucie stało się tak zwyczajne, że nikczemność (nequitia) była teraz sprawiedliwością (iustitia), i był ganiony, kto ją ganił, zamiast tego, który ją praktykował. Takie osoby, gnębione złym nawykiem, przypominają osoby pochowane".

47 Augustinus, Questionum in Heptateuchum 1, 45 (PSP 46/1, 31).

48 Contra Maximinum haereticum 2, 26.6: „W rzeczywistości ci patriarchowie są wskazani w Liście do Hebrajczyków, gdzie, mówiąc o gościnności, jest powiedziane: «z tą wiarą niektórzy, nie wiedząc, aniołom dali gościnę» (Hbr 13,2)". 


\section{Nierząd mężczyzn z mężczyznami (stupra in masculos)}

Wprawdzie już w ostatnim z głównych dzieł przeciw donatystom, napisanym w 419 r., biskup Hippony mówi o nierządzie (stuprum) ${ }^{49}$ w odniesieniu do zachowania się mężczyzn Sodomy wobec aniołó ${ }^{50}$, to jednak ten sposób interpretacji grzechu Sodomy ujawni się jeszcze bardziej w zaogniającym się konflikcie z wyjątkowo zagorzałym propagatorem pelagianizmu Julianem z Eklanum (386-455) ${ }^{51}$. Jednym z najbardziej newralgicznych punktów tego konfliktu było spojrzenie na seksualnośćs ${ }^{52}$. Podczas gdy Julian był zwolennikiem przesadnie optymistycznej wizji natury ludzkiej, Augustyn podkreślał jej skażoność pierwiastkami zła moralnego, które ma swoje źródło w grzechu pierworodnym. Biskupa Hippony zatrważała moc pożądliwości (vis concupiscendi) w człowieku, owo radykalne i całościowe wewnętrzne rozbicie, ów bolesny rozdźwięk ze sobą samym, dlatego z czasem tak wyraźnie związał pożądliwość ze swoją nauką o łasce ${ }^{53}$. Ponieważ seksualność jest integralnym elementem natury ludzkiej, dlatego też doktor Kościoła bronił jej zarówno przed surowym i bezdusznym manicheizmem, jak i płytkim i optymistycznym pelagianizmem. Stanowisko Augustyna było z kolei dla Juliana zbyt ascetyczne i z tej racji podkreślał, że złe i grzeszne jest jedynie nadmierne uleganie pożądliwości ${ }^{54}$.

Eoghan Ahern, śledząc spór Augustyna z Julianem, dostrzega, że od momentu, kiedy Julian w dziele Ad Turbantium (napisanym ok. 419 r.) włączy napomnienie apostoła Pawła z Rz 1,27 w interpretację grzechu Sodomy, również Augustyn podejmie ten tekst w swoich rozważaniach ${ }^{55}$. Trzeba tu przypomnieć, że powstanie polemicznego pisma Ad Turbantium łączy się bezpośrednio z napisaną przez biskupa Hippony pierwszą księgą dzieła De nuptiis et concupiscentia, w którym zasadniczo reasumuje podstawowe tezy swojego poprzedniego traktatu De bono coniugali. Dzieło to biskup Hippony adresuje do swojego przyjaciela komesa Waleriusza, urzędnika dworu cesarskiego w Rawennie, i ukazuje w nim dobro małżeństwa pomimo zła grzechu i pożądliwości. Przeciwko temu dziełu, rozdrażniony m.in. złożeniem z urzędu i przymusową emigracją na Wschód Julian, pisze aż cztery księgi. Ponieważ dzieło Juliana było obszerne, stąd bardzo szybko uczyniono z niego skrót i przesłano m.in. do Waleriusza, a Waleriusz z kolei do Augustyna z prośbą o ustosunkowanie

49 Biskup Hippony rzeczownika stuprum - rozumianego jako nierząd, nielegalne współżycie, nieakceptowane zachowanie - używa często w swoich rozważaniach o konkubinacie. Por. Łupiński, „The Concubinage", 263.

50 Por. Augustinus, Contra Gaudentium Donatistarum episcopum libri duo 1, 21.25.

51 Por. Ahern, „The Sin of Sodom”, 224.

52 Por. Grossi, „Sessualitä, 1306-1308.

53 Por. Burnell, „Concupiscenza”, 444; Drączkowski, Patrologia, 381.

54 Por. Beatrice, „Sessualità”, 3170; Campenhausen, Ojcowie Kościoła, 328-330; Chadwick, Augustyn, 163-167; Kornatowski, Społeczno-polityczna myśl św. Augustyna, 166; Piccolomini - Monopoli, L’attualità di Agostino, 175.

55 Por. Ahern, „The Sin of Sodom”, 225. 
się $^{56}$. Odpowiedzią Augustyna jest druga księga De nuptiis et concupiscentia, w której dokonuje on egzegezy Rz 1,26-27 w kontekście pelagiańskiej koncepcji pożądliwości cielesnej oraz trudności w uznaniu grzechu pierworodnego.

Wyjaśnienie apostoła Pawła, zdaniem Augustyna, koncentruje się nie na współżyciu małżeńskim, ale na współżyciu naturalnym (usu naturali), poprzez które rozumie się zjednoczenie tych części, które zostały tak stworzone, aby dwie płcie mogły wypełnić swoje zadanie prokreacyjne $e^{57}$. Boży porządek stworzenia (porządek natury) naruszają inne formy kontaktu seksualnego niż tradycyjny stosunek płciowy (waginalny stosunek płciowy), które według biskupa Hippony są jeszcze gorsze od relacji pozamałżeńskich ${ }^{58}$. Aktami przeciw naturze są także czyny nieczyste mężczyzn popełniane $\mathrm{z}$ innymi mężczyznami.

Według ciebie Apostoł chwalił namiętność dlatego, że nazwał stosunek z kobietą naturalnym. Powołujesz się na słowa św. Pawła: „Niektórzy zaniechawszy naturalnego stosunku z kobietą zapłonęli pożądaniem jeden do drugiego" (Rz 1,27 - Ad Turb. 1). Stąd, jak mniemasz, musisz pochwalić wszelki stosunek z kobietą, a czy dlatego pochwalasz wszelki nierząd popełniony z kobietami, że w tym wypadku ów stosunek jest naturalny, choć godny potępienia, bo jest nieprawy? Wobec tego dzieci nieprawe, które rodzą się z nieprawych związków nazywają się naturalnymi. Przeto Apostoł w tym zdaniu nie pochwala pożądliwości, lecz nazwał wymieniony stosunek naturalnym skąd natura ludzka może istnieć przez narodzenie ${ }^{59}$.

Zdaniem Juliana pożądliwość może być kontrolowana poprzez wolę i sama w sobie nie jest zła, ale dobra. Każde współżycie mężczyzny z kobietą jest naturalne i godne pochwały. Z takim ujęciem nie zgadzał się biskup Hippony, uważając, że zło pożądania (malum libidinis) nie zależy od jego dobrego użycia w małżeństwie. Dezaprobata biskupa Hippony dla poglądów Juliana wzrosła jeszcze bardziej, gdy ten w wyjaśnianiu zepsucia mężczyzn z Sodomy przesunął akcent z pożądliwości cielesnej na pożądliwość obfitości dóbr (saturitas panum et abundantia uini), błędnie cytując przy tym Ez 16,49.

56 Por. Cipriani, „Agostino di Ippona”, 48.

57 Augustinus, De nuptiis et concupiscentia 2, 20.35: „Jeśli chodzi o słowa Apostoła: «Porzucili naturalne współżycie z kobietą, zapałali nawzajem żądzą ku sobie, mężczyźni z mężczyznami uprawiając bezwstyd» (Rz 1,27), on nie mówi o używaniu małżeńskim, ale o naturalnym użyciu [non dixit usum coniugalem, sed naturalem], chcąc zaznaczyć, co dzieje się z utworzonymi członkami właśnie po to, aby obie płcie mogły się przez nich zjednoczyć w celu prokreacji”.

58 Augustinus, De nuptiis et concupiscentia 2, 20.35: „Jeśli ktoś łączy się ze swoim współmałżonkiem w tej części, która nie jest ustanowiona dla zrodzenia [quae non ad generandum est instituta], popełnia czyn przeciw naturze i haniebny”. Por. Hunter, „Etica sessuale”, 684-685. 
Powiadasz, że Sodomici zgrzeszyli używając chleba i wina ( $\operatorname{Rdz} 19,5)$. Stąd wnosisz, że pożądliwość sama w sobie jest dobra, natomiast ludzie, którzy jej nadużywają są winowajcami (Ad Turb. 1). Tak samo dobry jest chleb i dobre jest wino, chociaż ich nadużywanie jest grzeszne. [...] Pożądliwość jest złem, czy kto z nim walczy, czy mu ulega. Dobrze pożądliwością posługuje się rodzic, gdy w skromności syna rodzi, oraz Bóg troskliwie stwarzając człowieka ${ }^{60}$.

Biskup Hippony nie ma najmniejszej wątpliwości, że chleb i wino nie mogą być potępione, ponieważ niektórzy mężczyźni są bezbożni i rozpustni. W swoich rozważaniach poświęconych zaślepieniu serca podkreśla wyraźnie w kontekście bezbożnych namiętności mieszkańców Sodomy, że uczynki te są grzechami i karą wynikającą z poprzednich grzechów.

Zatroszczył się Apostoł, by powiedzieć, na czym polega kara oddania przez Boga na łup sromotnych namiętności, obojętnie, czy to wyłącznie sprowadza się do opuszczenia, czy do jakiegokolwiek zrozumiałego czy niezrozumiałego sposobu, którym posługuje się Najlepszy, Najsprawiedliwszy: „Albowiem niewiasty ich naturalny sposób pożycia przemieniły w ten, który jest przeciw naturze. A podobnie i mężczyźni zaniechając naturalnego stosunku z kobietą, zapłonęli pożądaniem jeden ku drugiemu, aby mężczyźni z mężczyznami dopuszczając się nieprzyzwoitości, wzajemnie należną zapłatę swego błędu na sobie ponieśli” (Rz 1,26-27) ${ }^{61}$.

W traktacie Contra mendatium, napisanym w 420 r., biskup Hippony zestawia przykład gościnności Lota z pełną odwagi postawą Rachab z Jerycha, która w swym domu ukryła wywiadowców Jozuego (Joz 2). Choć Lot naraził swoje córki na gwałt, to jednak, w przeciwieństwie do Rachab, nie skłamał, aby ocalić swoich gości. W zestawieniu tym, a raczej w opisie doświadczenia Lota, w bezpośrednim odniesieniu do postawy mieszkańców Sodomy, biskup Hippony mówi wyraźnie o mężczyznach rozpłomienionych niegodziwymi pożądliwościami ${ }^{62}$.

Eoghan Ahern zauważa, że użyte przez Augustyna sformułowanie „masculi in masculos” („mężczyźni z mężczyznami”) jest - podobnie jak u Gaudencjusza biskupa Brescii i Pawła Orozjusza - parafrazą Rz 1,27. Co więcej, w tym kontekście występuje tylko u biskupa Hippony, który w traktacie Contra mendacium zespolił wyjaśnienie z Rz 1,27 z myślą o tym, że mężczyźni z Sodomy pragnęli uprawiać czyny

\footnotetext{
60 Augustinus, Contra Iulianum libri sex 3, 20.41 (PSP 19/1, 212).

61 Augustinus, Contra Iulianum libri sex 5, 3.10 (PSP 19/2, 91).

62 Augustinus, Contra mendacium liber unus 17, 34: „Nie wolno nam zapominać, że tego rodzaju interwencja miała miejsce w Sodomie, kiedy mężczyźni rozpłomienieni niegodziwymi pożądliwościami [ubi masculi in masculos nefanda libidine accensi] nie mogli znaleźć drzwi do domu, w którym przebywali poszukiwani".
} 
nieczyste $\mathrm{z}$ aniołami ${ }^{63}$. W innej wypowiedzi z tego okresu, w XVI księdze De civitate Dei, opinia Augustyna o grzechu mieszkańców Sodomy jest jednoznaczna.

Po tej obietnicy i po uwolnieniu Lota z Sodomy, deszcz ognisty z nieba w popiół obrócił miasto owo bezbożne wraz z całą okolicą (Rdz 19,24-25), gdzie rozpusta mężczyzn z mężczyznami stała się tak zwykłym i codziennym zjawiskiem, jak inne jakie czyny dozwolone zazwyczaj przez prawa. Ale była też ta kara na Sodomitów obrazem przyszłego sądu Bożego ${ }^{64}$.

Pomimo że nad słowami Augustyna: „ubi stupra in masculos in tantam consuetudinem convaluerant” („gdzie rozpusta mężczyzn z mężczyznami stała się tak zwykłym i codziennym zjawiskiem"), dyskutowało się już dużo w kwestii ujęcia chrześcijańskich poglądów na temat homoseksualizmu ${ }^{65}$, to jednak, zdaniem Eoghana Aherna, należałoby większą uwagę zwrócić na kryjącą się w słowach biskupa Hippony parafrazę słów apostoła Pawła z Rz 1,2766.

Kwestia haniebnych czynów mieszkańców Sodomy pojawia się po raz ostatni w końcowym etapie sporu Augustyna z Julianem, gdy dysputa odnosiła się do kwestii wyniszczenia Kananejczyków. Julian, widząc ich winę w uczynkach dokonanych przy udziale wolnej woli, a była nią obraza Boga, świętokradztwo, czyli składanie własnych dzieci na ofiarę bogom, wyśmiewał przy tym grzech pierworodny jako przestępstwo wymyślone przez Manichejczyka, tj. Augustyna. Biskup Hippony zwraca uwagę na zepsucie ludzkiej natury zaczynające się od grzechu pierworodnego, który Julian stanowczo odrzucał; ponadto wykazuje nieprawidłowość w myśleniu Juliana i zarzuca mu, że jeżeli przyjąć, że grzechu pierworodnego nie ma, bo nie został przypomniany w tekście, który zacytował, to również nie powinny być grzechami inne grzechy, które także w tym tekście nie zostały wspomniane. W kolejnym etapie swojej argumentacji Augustyn stosuje podwójne przeczenie w dwu następujących po sobie zdaniach pytających, przy czym mieszkańcom Sodomy przypisuje praktykowanie magii i składanie w ofierze dzieci, a Kananejczykom czyny haniebne mężczyzn z mężczyznami (masculi in masculos turpitudinem operabantur) ${ }^{67}$. W końcowej odpowiedzi na pytanie: Dlaczego karą objęte zostały także niewinne dzieci kananejskie? Augustyn podkreśla, że w dostępnym nam wyjaśnieniu przyczyny została przypomniana nie tylko ich złośliwość (malitia) dobrowolna, ale i naturalna, do której oprócz skażenia powszechnego dołączyło się coś więcej jako konsekwencja przekleństwa Noego rzuconego na Kanaana ${ }^{68}$.

63 Por. Ahern, „The Sin of Sodom”, 225-226.

64 Augustinus, De civitate Dei 16, 30 (Kubicki, 629).

65 Por. Grassi, Sodoma, 29.

66 Ahern, „The Sin of Sodom”, 226.

67 Augustinus, Contra secundam Iuliani responsionem imperfectum opus 4, 128.

68 Augustinus, Contra secundam Iuliani responsionem imperfectum opus 4, 128. 


\section{Konkluzja}

Źródłowy opis o dwu podróżnych (aniołach) przybyłych do Sodomy wieczorem (Rdz 19,1-11) prowadzi św. Augustyna do rozważań nad postawą wobec nich zarówno Lota, jak i pozostałych mieszkańców Sodomy. Lot, którego biskup Hippony postrzega w głównej mierze w kontekście jego bogobojnego i hojnego stryja Abrahama, to człowiek sprawiedliwy, który nie tylko wiernie czcił ,jednego Boga prawdziwego", ale i nie dał się nakłonić do prowadzenia życia podobnego mieszkańcom Sodomy. Myśliciel z Tagasty w swym duchowym portrecie Lota nie eliminuje ani nie usprawiedliwia jego mniej wyrazistych i przemawiających rysów, zwłaszcza wydania mężczyznom z Sodomy swoich córek. Najbardziej jednak pochwala jego gościnność i zestawia ją z tą, której w rzeczywistości zabrakło mieszkańcom Sodomy. Już z samego zestawienia słów, których używa biskup Hippony: flagitia, facta mala, iniquitates et perversitates, scelera czy peccatum, wyraźnie wynika, że nie pochwala on ich czynów. Ta widoczna dezaprobata doktora Kościoła ma związek w pierwszej kolejności z faktem, że były to czyny przeciw naturze (flagitia contra naturam), przeciw Bożemu porządkowi (contra ordo divinus). Czyny te nie były bliżej precyzowane przez biskupa Hippony aż do momentu, kiedy w dyspucie z Julianem z Eklanum został zmuszony, aby zwłaszcza na podstawie Rz 1,26-27, bronić stosunku seksualnego zgodnego z Bożym porządkiem, a także, aby grzechu mieszkańców Sodomy nie sprowadzać do ogólnego nadużycia.

Obraz złych czynów mieszkańców Sodomy, jaki wyłania się z licznych wypowiedzi biskupa Hippony, jest zasadniczo dwuwątkowy, dwutorowy. Jednostronne więc czy też wybiórcze ujęcie go jest niepełne, a nawet szkodliwe. O ile pierwszy wątek, a więc uszanowanie świętego prawa gościnności, przynależy do dobrze znanej już od starożytności tradycji, którą św. Augustyn nie tylko przejmuje, ale i pieczołowicie kultywuje, podobnie jak np. św. Ambroży, tak drugi wątek odsłania wyraźnie toczącą się w V w. debatę teologiczną na takie tematy, jak: grzech pierworodny, pożądliwość czy seksualność człowieka. Dla biskupa Hippony współżycie niezgodne z Bożym zamysłem, czy to w obrębie małżeństwa, czy też poza nim, jest zawsze niegodziwe, haniebne i nieprzyzwoite. Stąd w piętnowaniu go używa w odniesieniu do mężczyzn z Sodomy terminów tak kategorycznych, jak: flagitia contra naturam („grzechy przeciw naturze”), stuprum („nierząd”) czy turpitudo („nieprzyzwoitość). Zmysłowość, seksualność przynależy do natury ludzkiej i sama w sobie nie jest czymś złym. Staje się jednak zła na skutek niekontrolowanej pożądliwości i może, jak w przypadku mieszkańców Sodomy, doprowadzić do całkowitej katastrofy. 


\section{SYLWESTER JAŚKIEWICZ}

\section{Bibliografia}

\section{Źródła}

Augustinus, Adnotationes in Iob liber unus (PL 34, 825-886).

Augustinus, Confessionum libri tredecim (PL 32, 659-868); tł. Z. Kubiak: Święty Augustyn, Wyznania (Warszawa: Instytut Wydawniczy PAX 1978).

Augustinus, Contra Faustum Manichaeum libri triginta tres (PL 42, 207-518); tł. J. Sulowski:

Święty Augustyn, Przeciw Faustusowi (Pisma Starochrześcijańskich Pisarzy 56; Warszawa:

Akademia Teologii Katolickiej 1991).

Augustinus, Contra Gaudentium Donatistarum episcopum libri duo (PL 43, 707-752).

Augustinus, Contra Iulianum libri sex (PL 44, 641-874); tł. W. Eborowicz: Św. Augustyn, Prze-

ciw Julianowi (Pisma Starochrześcijańskich Pisarzy 19/1-2; Warszawa: Akademia Teologii

Katolickiej 1977).

Augustinus, Contra Maximinum haereticum arianorum episcopum libri duo (PL 42, 743-814). Augustinus, Contra mendacium liber unus (PL, 40, 517-548).

Augustinus, Contra secundam Iuliani responsionem imperfectum opus (PL 45, 1049-1608).

Augustinus, De civitate Dei libri viginti duo (PL 41, 13-804); tł. W. Kubicki: Święty Augustyn,

Państwo Boże (Kęty: Antyk 1998).

Augustinus, De Haeresibus ad Quodvultdeum liber unus (PL 42, 21-50).

Augustinus, De mendacio liber unus (PL 40, 487-518).

Augustinus, De nuptiis et concupiscentia ad Valerium comitem libri duo (PL 44, 413-474).

Augustinus, Enarrationes in Psalmos (PL 36, 67-1028; PL 37, 1033-1966); tł. J. Sulowski: Święty

Augustyn, Objaśnienia Psalmów. Ps 58-77. Ps 124-150 (Pisma Starochrześcijańskich Pisarzy 39, 42/1; Warszawa: Akademia Teologii Katolickiej 1986).

Augustinus, Questionum in Heptateuchum libri septem (PL 34, 547-824); t1. J. Sulowski: Święty Augustyn, Problemy Heptateuchu (Pisma Starochrześcijańskich Pisarzy 46/1; Warszawa:

Akademia Teologii Katolickiej 1990) I.

Augustinus, Sermones (PL 38, 23-994).

\section{Źródła pomocnicze}

Ambroży z Mediolanu, Hexaemeron (tł W. Szołdrski) (Pisma Starochrześcijańskich Pisarzy 4; Warszawa: Akademia Teologii Katolickiej 1969).

Ambroży z Mediolanu, Listy. III. 70-77 (red. J. Naumowicz; tł. P. Nowak) (Biblioteka Ojców Kościoła; Kraków: Wydawnictwo M 2012).

Ireneusz, Przeciw herezjom, http://www.textexcavation.com/irenaeusah4.html [dostęp: 24.02.2021].

Justyn Męczennik, „1 Apologia”, Pierwsi apologeci greccy. Kwadratus, Arystydes z Aten, Aryston $z$ Pelli, Justyn Męczennik, Tacjan Syryjczyk, Milcjades, Apolinary z Hierapolis, Teofil z Antiochii, Hermiasz (red. J. Naumowicz; tł. L. Misiarczyk) (Biblioteka Ojców Kościoła 24; Kraków: Wydawnictwo M 2004) 207-270.

Orygenes, Przeciw Celsusowi, wyd. 2 (tł. S. Kalinowski) (Warszawa: Akademia Teologii Katolickiej 1986). 


\section{ZŁE CZYNY MIESZKAŃCÓW SODOMY (RDZ 19,1-11) W INTERPRETACJI ŚW. AUGUSTYNA}

\section{Studia}

Ahern, E., „The Sin of Sodom in Late Antiquity”, Journal of the History of Sexuality 27/2 (2018) 209-233.

Anagnostou-Laoutides, E., „Luxuria and Homosexuality in Suetonius, Augustine, and Aquinas”, The Mediaeval Journal 5/2 (2015) 1-32.

Beatrice, B.F., „Sessualità”, Dizionario patristico e di antichità cristiane (red. A. Di Berardino) (Casale Monferrato: Marietti 1983) II, 3166-3171.

Burnell, P., „Concupiscenza”, Dizionario patristico e di antichità cristiane (red. A. Di Berardino) (Casale Monferrato: Marietti 1983) II, 443-448.

von Campenhausen, H., Ojcowie Kościoła (tł. K. Wierszyłowski) (Warszawa: Cyklady 1998).

Carden, M., Sodomy. A History of a Christian Biblical Myth (London: Equinox Publishing 2004).

Chadwick, H., Augustyn (tł. T. Szafrański) (Warszawa: Prószyński i S-ka SA 2000).

Cipriani, N., „Agostino di Ippona”, Letteratura patristica (red. A. Di Berardino - G. Fedaldo M. Simonetti) (Roma: San Paolo 2007) 38-51.

Coyle, J.K., „Faustum Manichaeum, Contra”, Agostino. Dizionario enciclopedico (red. A.D. Fitzgerald; red. wł. L. Alici - A. Pieretti) (Roma: Città Nuova 2007) 711-713.

Crompton, L., Homosexuality and Civilization (Cambridge, MA - London: Belknap Press of Harvard University Press 2003).

Daniélou, J., Święci „poganie” Starego Testamentu. Pisma wybrane (tł. S. Fedorowicz) (Kraków: WAM 2013).

Drączkowski, F., Patrologia, wyd. 2 (Pelplin - Lublin: Bernardinum 1999).

Grassi, U., Sodoma. Persecuzioni, affetti, pratiche sociali (secoli V-XVIII) (Roma: Carocci 2019).

Grossi, V., Leggere la Bibbia con S. Agostino (Brescia: Queriniana 1999).

Grossi, V., „Sessualità, Agostino. Dizionario enciclopedico (red. A.D. Fitzgerald; red. wł. L. Alici - A. Pieretti) (Roma: Città Nuova 2007) 1305-1308.

Hogan, L., „Homosexualität im Alten Und Neuen Testament”, Homosexualität aus katholischer Sicht (red. A. Laun) (Eichstätt: Sales 2001) 151-160.

Hunter, D.G., „Etica sessuale”, Agostino. Dizionario enciclopedico (red. A.D. Fitzgerald; red. wł. L. Alici - A. Pieretti) (Roma: Città Nuova 2007) 684-686.

Jordan, M.D., The Invention of Sodomy in Christian Theology (Chicago, IL: University of Chicago Press 1997).

Kornatowski, W., Społeczno-polityczna myśl św. Augustyna (Warszawa: Instytut Wydawniczy Pax 1965).

Lemański, J, Księga Rodzaju. Rozdziały 11,27-36,43 (Nowy Komentarz Biblijny. Stary Testament 1/2; Częstochowa: Edycja Świętego Pawła 2014).

Lewandowski, P., Grzech sodomii w przestrzeni politycznej, prawnej i społecznej polski nowożytnej (E-bookowo 2014) [EPUB].

Loader, J.A., A Tale of Two Cities. Sodom and Gomorrah in the Old Testament, early Jewish, early Christian Traditions (Kampen: Kok 1990).

Łupiński, J., „The Concubinage of St. Augustine”, Studia Teologiczne. Białystok, Drohiczyn, Łomża 35 (2017) 261-279.

de Margerie, B., Introduction à l'histoire de l'exégèse. III. Saint Augustin (Paris: Cerf 2009). 
Pacioni, V., „Ordine”, Agostino. Dizionario enciclopedico (red. A.D. Fitzgerald; red. wł. L. Alici A. Pieretti) (Roma: Città Nuova 2007) 1029-1030.

Papieska Komisja Biblijna, „Czym jest człowiek?” (Ps 8,5). Zarys antropologii biblijnej (tł. H. Witczyk) (Kielce: Jedność 2020).

Piccolomini, R. - Monopoli, N., Lattualità di Agostino. Commento alla Lettera apostolica «Agostino d'Ippona» di Giovanni Paolo II (Roma: Città Nuova 1976).

Skrzydlewski, W.B., Etyka seksualna. Przemiany i perspektywy (Kraków: Wydawnictwo M 1999).

Sodoma distrutta. Le parole dei Santi e Papi contro l'omosessualismo (wprowadzenie med. S. De Mari) (Cermentate: Edizioni Radio Spada 2018).

Spindelböck, J., „Die sittliche Beurteilung der Homosexualität. Moralhistorische Anmerkungen zum christlichen Standpunkt", Homosexualität aus katholischer Sicht (red. A. Laun) (Eichstätt: Sales 2001) 161-178.

„Tavola delle opere di Agostino. Note”, Agostino. Dizionario enciclopedico (red. A.D. Fitzgerald; red. wł. L. Alici - A. Pieretti) (Roma: Città Nuova 2007) 43-66.

Vaccaro, J.L., „Abramo”, Agostino. Dizionario enciclopedico (red. A.D. Fitzgerald; red. wł. L. Alici - A. Pieretti) (Roma: Città Nuova 2007) 105.

Van Fleteren, F., „Confessiones (Le confessioni)”, Agostino. Dizionario enciclopedico (red. A.D. Fitzgerald; red. wł. L. Alici - A. Pieretti) (Roma: Città Nuova 2007) 448-457. 